\title{
Venous thromboembolism in women: new challenges for an old disease
}

\author{
Tromboembolismo venoso na mulher: novos desafios para uma velha doença \\ André Luiz Malavasi Longo de Oliveira' (D), Adilson Ferraz Paschôa² (D), Marcos Arêas Marques ${ }^{3,4}$ (D)
}

\begin{abstract}
In countries that have controlled classic causes of maternal death, such as eclampsia and hemorrhage, venous thromboembolism (VTE) has become the major concern. Prevention of VTE during pregnancy and postpartum by applying guidelines and implementing pharmacoprophylaxis is still the best strategy to reduce occurrence of this complication. Hormonal contraceptives and hormone replacement therapy also increase the risk of VTE, but women cannot be deprived of their benefits, which increase their freedom at childbearing age and reduce their symptoms at menopause. Both indiscriminate use and unmotivated prohibition are inappropriate. Contraceptive and hormone replacement methods should be chosen with care, evaluating the patients' contraindications, eligibility criteria, and autonomy. This article presents a nonsystematic review of recent literature with the aim of evaluating and summarizing the associations between VTE and clinical situations peculiar to women.
\end{abstract}

Keywords: thrombosis; contraceptive agents; pregnancy; hormone replacement therapy; women; pulmonary embolism.

\section{Resumo}

Nos países que controlaram as causas clássicas de óbito materno, como eclâmpsia e hemorragia, o tromboembolismo venoso (TEV) passou a ser a principal preocupação. A prevenção do TEV na gestação e no puerpério, por meio de diretrizes e da instituição de farmacoprofilaxia, é ainda a melhor estratégia para reduzir essa complicação. Os contraceptivos hormonais e a terapia de reposição hormonal também aumentam o risco de TEV; porém, as mulheres não podem ser privadas dos benefícios dessas terapias, que as tornam mais livres na idade fértil e menos sintomáticas na menopausa. Tanto o uso indiscriminado quanto a proibição imotivada são inadequados. A escolha dos métodos contraceptivos e de reposição deve ser feita por criteriosa seleção, avaliando as contraindicações, os critérios de elegibilidade e a autonomia das pacientes. O presente artigo apresenta uma revisão não sistemática da literatura recente visando a avaliar e resumir a associação entre TEV e situações clínicas peculiares ao sexo feminino.

Palavras-chave: trombose; anticoncepcionais; gravidez; terapia de reposição hormonal; mulheres; embolia pulmonar.

How to cite: Oliveira ALML, Paschôa AF, Marques MA. Venous thromboembolism in women: new challenges for an old disease. J Vasc Bras. 2020;19:e20190148. https://doi.org/10.1590/1677-5449.190148

\footnotetext{
${ }^{1}$ Centro de Referência da Saúde da Mulher do Estado de São Paulo, Obstetrícia e Ginecologia, São Paulo, SP, Brasil.

${ }^{2}$ Hospital da Beneficência Portuguesa de São Paulo, Cirurgia Vascular, São Paulo, SP, Brasil.

${ }^{3}$ Universidade do Estado do Rio de Janeiro - UERJ, Hospital Universitário Pedro Ernesto, Unidade Docente Assistencial de Angiologia, Rio de Janeiro, RJ, Brasil.

${ }^{4}$ Universidade Federal do Estado do Rio de Janeiro - UNIRIO, Hospital Universitário Gafrée e Guinle, Serviço de Cirurgia Vascular, Rio de Janeiro, RJ, Brasil. Financial support: None.

Conflicts of interest: No conflicts of interest declared concerning the publication of this article.

Submitted: November 27, 2019. Accepted: April 29, 2020
}

The study was carried out at Unidade Docente Assistencial de Angiologia, Hospital Universitário Pedro Ernesto, Universidade do Estado do Rio de Janeiro (UERJ), Rio de Janeiro, RJ, Brazil. 


\section{VENOUS THROMBOEMBOLISM IN PREGNANCY}

Modern obstetrics is faced by a bleedingthromboembolism duality dilemma. If, in the not too distant past the greatest dread among those who cared for women giving birth was accidental hemorrhage, nowadays, this fear is compounded by another complication: venous thromboembolism (VTE). ${ }^{1,2}$

Pregnant women have all three etiopathogenic components of Virchow's triad: a) venous stasis, caused by compression of the vena cava and left common iliac vein by the gravid uterus and by reduced venous tone because of the myorelaxant action of progesterone; b) hypercoagulability, secondary to induction of hepatic synthesis of coagulation factors VII, VIII, and X by placental estriol, increased levels of fibrinogen and plasminogen activator inhibitor types I and II, and reduced synthesis of protein S; c) endothelial injury, which occurs during nidation, endovascular remodeling of uterine spiral arteries, and expulsion of the placenta. ${ }^{3}$

During pregnancy, the risk of VTE increases by between five and ten times, and can be 35 times higher during the puerperium, when compared with the rate among women of the same age who are not pregnant. ${ }^{4}$ After this period, the frequency reduces rapidly; but there is a residual risk for up to 12 weeks after delivery. ${ }^{5}$

Deep venous thrombosis (DVT) in the lower limbs is responsible for 75 to $80 \%$ of VTE episodes in pregnancy. Approximately two-thirds of DVTs occur during the prenatal period, equally distributed across the three trimesters of gestation. However, 43 to $60 \%$ of pulmonary embolism (PE) episodes occur during the first 6 weeks of the puerperium. ${ }^{6}$ When compared with women who are not pregnant, among pregnant women DVTs in the left lower limb (90\% vs. 55\%) and the iliofemoral segment ( $72 \%$ vs. $9 \%$ ) are even more predominant. This is because of the accentuated compression of the left common iliac vein against the fifth lumbar vertebra by the right common iliac artery, caused by the gravid uterus. ${ }^{3}$

The prevalence of VTE is in the range of 0.5 to 2.2 cases per 1,000 deliveries, depending on the study population, ${ }^{7}$ and the absolute incidence of VTE during pregnancy and the puerperium was 107 per 100,000 woman-years in the United Kingdom (UK) ${ }^{8}$ and 175 per 100,000 woman-years in Denmark and in Canada. ${ }^{9}$ There are no official data on maternal VTE mortality for Brazil. ${ }^{6}$

Although PE remains the number one cause of direct maternal death in the UK, there was a significant fall in the rate linked with vaginal deliveries, from 1.56 per 100,000 deliveries in 2003-2005 to 0.70 per 100,000 deliveries in 2006-2008, which can be attributed to application of the first version (2004) of the Royal College of Obstetricians and Gynaecologists' (RCOG) guideline on reducing the risk of VTE in pregnancy and the puerperium. ${ }^{10}$ Prevention of VTE in pregnancy, by means of application of guidelines and the consequent implementation of mechanical and/or pharmacological prophylaxis is the best strategy for reducing the rate of these events. ${ }^{6}$

\section{RISK FACTORS FOR VTE DURING PREGNANCY}

\section{Overweight and obesity}

Obesity (body mass index $[\mathrm{BMI}]>30 \mathrm{~kg} / \mathrm{m}^{2}$ ) is an important risk factor for VTE in pregnancy and the risk grows as BMI increases, ${ }^{11}$ reaching as much as 14.9 times higher than the risk for women who are not obese. ${ }^{12}$ Sixty percent of the pregnant women who died from PE in the UK from 2003 to 2008 were obese. ${ }^{10}$ While maternal overweight (BMI from 25 to $29.9 \mathrm{~kg} / \mathrm{m}^{2}$ ) is common, it is considered a less important risk factor for pregnancy-related VTE. ${ }^{12}$

\section{Age}

Data extracted from studies with case-control designs suggest that women over the age of 35 years are at double the risk. ${ }^{13}$ In a study conducted in the UK, using a broad cohort of women who were not pregnant, those aged 35 to 44 years had a $50 \%$ higher risk of VTE when compared with those aged 25 to 34 years. The prenatal VTE rate did not increase with age, but women aged 35 to 44 years exhibited a $70 \%$ greater risk in the puerperal period when compared with those aged 25 to 34 years (an increase in absolute risk of 1.6 per 1,000 person-years). ${ }^{8}$ In general, age of 35 years or more is considered an antenatal and postnatal risk factor. ${ }^{14}$

\section{Thrombophilias}

Although there is an association between hereditary thrombophilias and VTE, systematic work-up for thrombophilias should not be conducted for all women, but restricted to patients with prior episodes or family history of thrombophilias with greater potential for complications, such as antithrombin deficiency and homozygosis of factor $\mathrm{V}$ Leiden and the 20210 prothrombin mutation, which may need VTE prophylaxis. Depending on the circumstances, 
this may be prescribed from the start of pregnancy up to puerperium, from the 28th week onwards, or just during puerperium. It is important to point out that clinical history is of greater relevance for this decision than the results of laboratory tests. In turn, the association between thrombophilias of genetic causes and uteroplacental thrombosis causing miscarriage, fetal growth restriction, or placental abruption, remains a controversial subject. ${ }^{15-17}$

\section{Long-distance travel and immobility}

There are limited data on immobility and long-distance travel in pregnant women, so it is necessary to extrapolate from studies of populations women pregnant who are not. ${ }^{18}$ Guidelines from the UK's National Institute of Health and Care Excellence (NICE) $^{19}$ and the recommendations of the RCOG on flying during gestation state that flights with duration exceeding 4 hours increase the risk of VTE. A Norwegian case-control study identified an increased risk of VTE in pregnant women with BMI $>25 \mathrm{~kg} / \mathrm{m}^{2}$ and prepartum immobilization (defined as confinement to bed for a period greater than or equal to 1 week before birth or before diagnosis of VTE), showing a multiplication effect on prenatal and postnatal risk of VTE. ${ }^{11}$

Hospital admission during pregnancy is associated with an 18-times increase in the risk of VTE compared with the baseline risk outside of hospital and the risk remains elevated after birth, for the next 28 days. When admitted to hospital, the risk is higher in the third trimester of pregnancy and in women over the age of 35 years. ${ }^{20}$

\section{Others}

Certain comorbidities have been associated with increased risk of VTE during pregnancy. These include inflammatory intestinal disease, urinary tract infection, systemic lupus erythematosus, heart diseases, pregnancy-induced systemic arterial hypertension or pre-eclampsia, and non-obstetric antenatal surgery. ${ }^{21}$ In an analysis of data from 1,475,301 discharges from Scottish hospital maternity units, Kane et al. found that risk factors associated with VTE included three or more previous gestations, obstetric hemorrhage, and pre-eclampsia. ${ }^{21}$ Hyperemesis increases prenatal and postnatal risk of VTE 4.4 times.

This information has important implications, since many thromboembolic events are fatal and occur during the first trimester, often before the first prenatal consultation, when antenatal prophylaxis may be initiated. ${ }^{22}$

\section{Factors related to anticoagulant treatment during gestation and puerperium}

Administration of warfarin during pregnancy can induce placental abruption, embryopathy, abnormalities of the central nervous system (CNS), and fetal bleeding. Warfarin embryopathy is characterized by nasal hypoplasia and/or stippling of the epiphyses and is associated with exposure to warfarin between the sixth and twelfth weeks of gestation. ${ }^{23}$ Central nervous system abnormalities associated with use of warfarin include dysplasia of the dorsal midline with agenesis of the corpus callosum, atrophy of the cerebellar midline, dysplasia of the ventral midline with optical atrophy and amaurosis, and hemorrhage, and can occur after exposure to warfarin at any phase of the gestation. Warfarin is safe when breastfeeding. ${ }^{24}$

Two approaches can be taken to reduce the risk of warfarin use in women who need anticoagulation and intend to become pregnant. The first is to maintain warfarin and conduct pregnancy tests frequently. As soon as pregnancy is detected, before the sixth week, low molecular weight heparin (LMWH) should be introduced to replace warfarin. The other approach is to withdraw warfarin and start LMWH as soon as the decision to become pregnant is taken. ${ }^{24-28}$

Although existing direct oral anticoagulants (apixaban, dabigatran, edoxaban, and rivaroxaban) have enabled major advances in prophylaxis and treatment of VTE in many clinical situations, they are contraindicated in pregnancy, because they cross the placental barrier, and in breastfeeding, because they pass into breast milk. ${ }^{6,23-25}$

\section{Caesarean}

Although the risk of VTE associated with caesarean in isolation is low, the rate of VTE occurrence becomes significant when there is a relationship with other risk factors, and so thromboprophylaxis should be prescribed.$^{29}$ Delivery of anticoagulated pregnant woman should be scheduled for 37 to 40 weeks. Low molecular weight heparin should be withdrawn 12 hours before delivery if given at prophylactic dosages, or 24 hours before if administered at intermediate or full dosages, enabling safe administration of spinal or epidural anesthesia. Pregnant women on LMWH should be instructed not to administer the dose if they experience contractions or release of liquids. ${ }^{23}$

The choice of delivery route is obstetric and there is no contraindication against artificial cervical ripening or induction of labor. The patient should continue wearing antiembolism stockings throughout the procedure, regardless of whether delivery is vaginal or caesarean. 


\section{Risk stratification}

Stratification of VTE risk in pregnancy is based on assessment of each patient and should be performed for all women who intend to become pregnant or as soon as they become pregnant. It is recommended that assessments are repeated throughout the prenatal period, since new risk factors could emerge. The patient's preferences and views should be taken into account when choosing thromboprophylaxis, even though the treatment options are restricted in this situation. ${ }^{26}$

The recommendations suggested are based on individual variations between patients and are intended to inform, rather than substitute, the physician's clinical judgment, which should determine the appropriate management for each case in the final analysis. The most relevant guidelines on the subject of diagnosis, prophylaxis, and treatment of VTE in pregnancy are those published by the American College of Obstetricians and Gynecologists (ACOG), ${ }^{30}$ the Society of Obstetricians and Gynaecologists of Canada (SOGC), ${ }^{31}$ the $\mathrm{RCOG},{ }^{27}$ and the American College of Chest Physicians (ACCP). ${ }^{28,29}$

\section{Summary of guidelines}

As mentioned above, the objective of the guidelines is to set out the most appropriate conduct on the basis of publications available in the literature. Notwithstanding, atypical situations are common and demand different treatment. The major guidelines are summarized below.

ACOG: intermittent pneumatic compression (IPC) before caesarean if the patient is not on thromboprophylaxis. ${ }^{30}$

SOGC: drug-based thromboprophylaxis is recommended postpartum in the following situations: prior VTE, high risk thrombophilia (antiphospholipid antibody syndrome, antithrombin deficiency, homozygosis of factor V Leiden or the G20210A mutation of the prothrombin gene, or combined thrombophilias), confinement to bed for 7 or days or more before delivery, bleeding exceeding $1 \mathrm{~L}$ during peripartum or postpartum, transfusion of blood products, postpartum surgery, and infection during peripartum or postpartum. ${ }^{31}$

Pharmacological thromboprophylaxis should be considered in the presence of two or more of the following: $\mathrm{BMI} \geq 30 \mathrm{~kg} / \mathrm{m}^{2}$ at first prenatal consultation, smoking $>10$ cigarettes/day, preeclampsia, fetal growth restriction, placenta previa, emergency caesarean, bleeding exceeding $1 \mathrm{~L}$ during peripartum or postpartum or transfusion of blood products, low-risk thrombophilia (deficiency of protein $\mathrm{C}$ or S, heterozygosis of factor V Leiden or the 20210A mutation of the prothrombin gene), maternal cardiac disease, systemic lupus erythematosus, sickle-cell anemia, intestinal inflammatory disease, varicose veins of the lower limbs, gestational diabetes, premature delivery, stillbirth; or three or more of the following risk factors: age $>35$ years, parity $\geq 2$, any type of assisted reproduction technique, multiple gestation, placental abruption, premature rupture of membranes, elective caesarean, or maternal cancer.

Women with persistent risk factors should be given pharmacological thromboprophylaxis for a minimum of 6 weeks postpartum, while those with transitory factors during prepartum and peripartum should be given pharmacological thromboprophylaxis up to hospital discharge, or 2 weeks postpartum. ${ }^{25}$

RCOG: emergency caesarean, for 10 days postpartum with prophylactic doses of LMWH; for all other patients delivered by caesarean, consider 10 days of LMWH at prophylactic doses if other risk factors are present. ${ }^{27}$

ACCP: in the absence of additional risk factors, early mobilization; in the case of one major risk factor or two or more minor ones (or one minor factor if emergency caesarean has been performed), prophylaxis with LMWH after delivery is suggested while the patient is still in hospital (in the presence of contraindications to anticoagulation, use mechanical prophylaxis with antiembolism stockings or IPC); in extremely high-risk cases, with additional risk factors that remain during puerperium, combine LMWH with antiembolism stockings and/or IPC; selected high risk patients with additional risk factors that remain during puerperium should be given up to 6 weeks extended pharmacological thromboprophylaxis after hospital discharge..$^{28,29}$

\section{Venous thromboembolism and contraception}

In Brazil, one in every five women use (OC) ${ }^{32}$ Oral contraceptives offer benefits that go beyond contraception, such as reduction of menstrual bleeding, dysmenorrhea, treatment of premenstrual syndrome, menstrual migraine, acne, and hirsutism. The long-term benefits include reduced rates of endometrial, ovarian, and colorectal cancer. ${ }^{30}$ Oral contraceptives are well-tolerated, serious side effects are rare, and compliance with use is high. ${ }^{31}$

Venous thromboembolism is a rare complication of OCs. ${ }^{31}$ The first report of increased risk of VTE associated with use of OCs was in $1961^{32}$ and since then many different studies have confirmed an increase of two to six times in the risk of VTE. The thromboembolic risk of OCs depends on the estrogen dosage and the type of progestogen combined with it. ${ }^{33,34}$ Oral contraceptives increase the risk of VTE from a baseline rate of 5/10,000 woman-years among non users 
to 9 to $10 / 10,000$ woman-years among users. ${ }^{34}$ To keep this risk in perspective, it is important to remember that the risk of VTE is $29 / 10,000$ during pregnancy and 300-400/10,000 in puerperium..$^{35}$ These impressive figures confirm that, in many clinical situations, health professionals advising women not to take OCs verges on the irresponsible.

Older OCs, with high estrogen levels $(>50 \mu \mathrm{g}$ of ethinylestradiol) are linked with a greater risk of VTE than modern OCs $(<50 \mu \mathrm{g}$ of ethinylestradiol). Notwithstanding, no reduction of risk was confirmed with pills containing $20 \mu \mathrm{g}$ of ethinylestradiol compared with pills containing $30 \mu \mathrm{g}$ of ethinylestradiol. ${ }^{34}$ Although OCs with less than $35 \mu \mathrm{g}$ ethinylestradiol provoked fewer side effects related to estrogen, such as nausea and increased breast sensitivity, during the first months of use, a reduction in risk of VTE was not demonstrated. ${ }^{36}$

The risk of VTE among women on OCs is attributed to changes in hemostasis. ${ }^{37}$ Estrogen increases serum concentration of coagulation factors (prothrombin, factors VII, VIII, and X, and fibrinogen) and reduces concentration of anticoagulant factors (protein $\mathrm{S}$ and antithrombin). ${ }^{38}$ These changes can have a clinical impact in women with hereditary thrombophilias..$^{39}$ The risk of VTE associated with OCs increases with the estrogen dose, with increased body weight and age, and with reintroduction or change of OC after a withdrawal exceeding 4 weeks. ${ }^{34}$ The type of progestogens also influences the risk of VTE, and second-generation progestogens (levonorgestrel [LNG] and norethisterone) are safer than third and fourth-generation ones. ${ }^{40}$ The new generations of progestogens are partly responsible for the non-contraceptive benefits of OCs. ${ }^{31}$ Oral contraceptives containing third-generation progestogens have fewer androgenic effects and possibly lower metabolic and cardiovascular risk, but possibly with an increased risk of VTE. ${ }^{31}$

Among users of OCs, those with hereditary thrombophilia, smokers, and the obese are at higher risk of VTE. Recognizing this increased risk, the World Health Organization (WHO) advises against use of OCs by women with these factors. However, because of the low prevalence of hereditary thrombophilias and the high cost of screening for them, routine testing for thrombophilias is not recommended by the WHO. ${ }^{41}$

Presence of a family history of VTE is a strong and common risk factor for OC-linked VTE, even in the absence of hereditary thrombophilias. ${ }^{42}$ The risk of VTE for a woman who takes OC and has a family history of VTE is 15.3 times higher than for a woman who do not take OCs and does not have a family history of VTE. ${ }^{43}$
There is no consensus on the best $\mathrm{OC}$ to prescribe. There is, however, an understanding that second-generation progestogens should be the first choice for the majority of women. . $^{44,45}$

Non-oral contraceptives, including patches and vaginal rings, are also associated with increased risk of VTE, raising the risk of VTE by 7.9 and 6.5 times, respectively. ${ }^{45}$ Several different studies report that the risk of VTE is higher during the first year of use, probably because of undiagnosed thrombophilias. ${ }^{46}$ Coagulation does not exhibit significant changes with progesterone-only OCs, implants containing LNG, or medroxyprogesterone injection in depot form. ${ }^{47}$ Normal or increased sensitivity to active $\mathrm{C}$ protein was reported 3 months after insertion of the levonorgestrel intrauterine system (LNG-IUS), indicating that this contraceptive does not have pro-thrombotic effects. ${ }^{48}$

\section{Venous thromboembolism and assisted fertilization}

Infertility affects more than $10 \%$ of couples worldwide. ${ }^{49,50}$ In vitro fertilization (IVF) is a process in which ovarian cells are fertilized by spermatozoa outside of the body and is the most widely-used technique for human reproduction in infertile couples. ${ }^{51,52}$ Venous thromboembolism is a rare complication in women who undergo IVF and occurs in 0.1 to $2.4 \%$ in each fertilization cycle. ${ }^{53-57}$ The risk of VTE is double during prenatal period after IVF (odds ratio [OR] 2.18; 95\% confidence interval [95\%CI] 1.63-2.92), when compared with the baseline risk of other pregnant women. This is because of a five-to-ten-times increase in the risk of VTE during the first trimester of gestations after IVF, partly because of the very high risk of VTE in ovarian hyperstimulation syndrome (OHS), which is a iatrogenic and potentially fatal complication that occurs in $33 \%$ of all cycles generated by IVF. ${ }^{58}$ The incidence of VTE after IVF is $0.1 \%$ in cycles without OHS and from $0.8 \%$ to $2.4 \%$ of those in which OHS occurs. ${ }^{53-57}$ Women who have OHS are at 100 times greater risk of VTE $^{59}$ and, in severe OHS, thromboprophylaxis with LMWH reduces 26 cases of VTE for every 1,000 women treated (number necessary to treat [NNT] is 39 , based on a baseline VTE risk of 4\%), without significant increase in bleeding. ${ }^{24}$ Venous thromboembolism occurs with greatest frequency between the 40th and 42nd days after transfer of the embryo. In vitro fertilization also increases the risk of arterial thrombosis, which occurs earlier, on average on the 10th day after transfer of the embryo. ${ }^{58,60,61}$

Venous thromboembolism associated with IVF has a propensity to sites in the upper extremities and 
the cervical region, rather than in the left lower limb, as is more common in spontaneous pregnancies. ${ }^{60-67}$

In addition to OHS, other obstetric complications are related to a greater risk of VTE in patients who undergo IVF: multiple gestations, prematurity, fetal death, preeclampsia, and prenatal and postpartum hemorrhage..$^{58-65,68}$

\section{Venous thromboembolism and hormone replacement therapy}

Venous thromboembolism is an uncommon event before menopause, but incidence increases considerably after this period, at around one event per 1,000 woman-years at around 50 years of age, and mortality is $10 \%$ in these cases. ${ }^{69-73}$

Risk factors for VTE include genetic predisposition (hereditary thrombophilias), constitutional factors (age, overweight, and obesity), comorbidities (cancer, heart failure, active systemic lupus erythematosus, antiphospholipid antibody syndrome, inflammatory polyarthropathy, inflammatory intestinal disease, nephrosis, diabetes mellitus type I with nephropathy, sickle-cell anemia, and intravenous drug use), use of tamoxifen, immobility, and surgery.

Although recent data show that the risks could outweigh the benefits for women who take hormone replacement therapy (HRT), many are still prescribed estrogens to minimize symptoms of the menopause, which can be an additional risk factor for VTE. Women who have a uterus are also given progestogens to neutralize the risk of endometrial cancer. ${ }^{69,74,75}$

A great variety of HRT can be used for women going through the menopause and the preparations can differ in terms of their adverse effects. There is evidence that the risk of VTE among users is dependent on the route of estrogen administration. In fact, the transdermal route is not associated with an increased risk of VTE among postmenopausal women..$^{71,75-86}$ Additionally, the type of concomitant progestogens was recently identified as an additional VTE risk factor in women who take HRT. ${ }^{75,87}$

Observational studies, systematic reviews, and metanalyses consistently report a two to three times greater risk of VTE among postmenopausal women on HRT. ${ }^{71,75,88-93}$ Women who have used HRT in the past have a similar VTE risk to those who have never used the treatment and, among those on HRT, risk is greatest during the first year of treatment. However, there are no consistent data on risk of VTE according to the method of HRT, including type and dose of estrogens, route of administration, and the potential role of progestogens. ${ }^{69,75}$

In order to prevent VTE in women who request HRT, it is important to identify susceptible subsets. Hereditary thrombophilias are well-established risk factors for VTE, increasing the risk by three times in postmenopausal women (OR 3.3; 95\% CI 2.6-4.1). ${ }^{88}$ The combination of these mutations with estrogen taken orally increases the risk of VTE (OR 8.0; 95\%CI 5.4-11.9) compared to the risk among women without these mutations and not taking estrogen. ${ }^{75}$ However, there was no difference in risk of VTE among women using the transdermal route when compared with women who did not use HRT. ${ }^{88}$

Women with a personal and family history of VTE are considered high risk and, therefore, are not candidates for HRT with oral route estrogen. Oral route estrogen provokes procoagulatory changes, such as increased resistance to active $\mathrm{C}$ protein, by reducing serum concentration of protein $\mathrm{S}$, probably because of passage of estrogen through the liver and reduction of fibrinolytic activity. ${ }^{75,94}$

These changes are not observed with the transdermal route. The impact of progestogens in postmenopausal women on HRT has been studied little. ${ }^{95-97}$

The Menopause, Estrogen and Venous Events Study (MEVE) investigated the association between transdermal estrogen and risk of VTE recurrence in 1,023 postmenopausal women with prior history of VTE. ${ }^{8}$ The results suggest that transdermal estrogen is safe with regard to VTE recurrence and confirmed that oral estrogen increased the risk of recurrence (relative risk [RR] 6.4; 95\%CI 1.59-27.3).

Hormone replacement therapy is the most effective treatment for climacteric symptoms associated with falling estrogen levels after menopause. ${ }^{74,75}$ After evaluation of the risks and benefits, HRT should be prescribed with the lowest estrogen dose and shortest duration possible. Current data do not support its use for primary or secondary prevention of cardiovascular diseases or dementia. ${ }^{71,75,98}$ Since PE is the greatest cause of death attributed to HRT among postmenopausal women aged 50-59 years, the reduced risk of VTE linked with HRT using transdermal estrogen alone or combined with micronized progestogen indicates that this is the most recommended strategy for improving the risk-benefit relationship of HRT. ${ }^{71}$ This strategy is confirmed in the North American Menopause Society and the European Menopause Society guidelines. ${ }^{75,99,100}$

\section{CONCLUSIONS}

Venous thromboembolism is a current challenge in obstetric practice, particularly after the reductions in hemorrhagic complications and infectious during pregnancy and puerperium observed in more developed settings. Preventative interventions of a mechanical and pharmacological nature reduce occurrence of VTE and its short and long-term complications. 
The implementation of several prophylaxis guidelines and protocols reflect concern with the quality of care provided to pregnant women. Irrespective, adequate attention to contraception and HRT also demand maturity and knowledge. Simply prohibiting use of OCs and HRT without carefully assessing risk factors and family and personal history, does not decisively combat occurrence of VTE and unnecessarily exposes woman to a risk of reduced quality of life.

\section{REFERENCES}

1. Say L, Chou D, Gemmill A, et al. Global causes of maternal death: a WHO systematic analysis. Lancet Glob Health. 2014;2(6):e323-33. http://dx.doi.org/10.1016/S2214-109X(14)70227-X. PMid:25103301.

2. Chan WS, Ray JG, Murray S, Coady GE, Coates G, Ginsberg JS. Suspected pulmonary embolism in pregnancy: clinical presentation, results of lung scanning, and subsequent maternal and pediatric outcomes. Arch Intern Med. 2002;162(10):1170-5. http://dx.doi. org/10.1001/archinte.162.10.1170. PMid:12020189.

3. Simcox LE, Ormesher L, Tower C, Greer IA. Pulmonary thromboembolism in pregnancy: diagnosis and management. Breathe. 2015;11(4):2829. http://dx.doi.org/10.1183/20734735.008815. PMid:27066121.

4. Greer IA. Thrombosis in pregnancy: updates in diagnosis and management. Hematology. 2012;2012(1):203-7. http://dx.doi. org/10.1182/asheducation.V2012.1.203.3798262. PMid:23233582.

5. Kamel H, Navi BB, Sriram N, Hovsepian DA, Devereux RB, Elkind MS. Risk of a thrombotic event after the 6-week postpartum period. N Engl J Med. 2014;370(14):1307-15. http://dx.doi.org/10.1056/ NEJMoa1311485. PMid:24524551.

6. Oliveira ALML, Marques MA. Profilaxia de tromboembolismo venoso na gestação. J Vasc Bras. 2016;15(4):293-301. http://dx.doi. org/10.1590/1677-5449.006616. PMid:29930607.

7. Heit JA, Kobbervig CE, James AH, Petterson TM, Bailey KR, Melton $\mathrm{LJ} 3 \mathrm{rd}$. Trends in the incidence of venous thromboembolism during pregnancy or postpartum: a 30-year population-based study. Ann Intern Med. 2005;143(10):697-706. http://dx.doi.org/10.7326/0003 4819-143-10-200511150-00006. PMid:16287790.

8. Sultan AA, West J, Tata LJ, Fleming KM, Nelson-Piercy C, Grainge MJ Risk of first venous thromboembolism in and around pregnancy: a population-based cohort study. Br J Haematol. 2012;156(3):366-73. http://dx.doi.org/10.1111/j.1365-2141.2011.08956.x. PMid:22145820.

9. Virkus RA, Lokkegaard EC, Bergholt T, Mogensen U, LanghoffRoos J, Lidegaard O. Venous thromboembolism in pregnant and puerperal women in Denmark 1995-2005: a national cohort study. Thromb Haemost. 2011;106(2):304-9. PMid:21713323.

10. Lewis G. Saving mothers' lives: reviewing maternal deaths to make motherhood safer - 2003-2005: the seventh report of the confidential enquiries into maternal deaths in the United Kingdom. London: CEMACH; 2007. 266 p.

11. Jacobsen AF, Skjeldestad FE, Sandset PM. Incidence and risk patterns of venous thromboembolism in pregnancy and puerperium-a register-based case-control study. Am J Obstet Gynecol. 2008;198(2):233.e1. http://dx.doi.org/10.1016/j.ajog.2007.08.041. PMid:17997389.

12. Larsen TB, Sorensen HT, Gislum M, Johnsen SP. Maternal smoking, obesity, and risk of venous thromboembolism during pregnancy and the puerperium: a population-based nested case-control study. Thromb Res. 2007;120(4):505-9. http://dx.doi.org/10.1016/j. thromres.2006.12.003. PMid:17257657.
13. Lindqvist P, Dahlback B, Marsal K. Thrombotic risk during pregnancy: a population study. Obstet Gynecol. 1999;94(4):595-9. http:// dx.doi.org/10.1097/00006250-199910000-00021. PMid:10511366.

14. Nelson-Piercy C. Handbook of obstetric medicine. New York: Informa Healthcare; 2010. http://dx.doi.org/10.3109/9781841847382.

15. Scifres $C M$, Macones GA. The utility of thrombophilia testing in pregnant women with thrombosis: fact or fiction? Am J Obstet Gynecol. 2008;199(4):344.e1-7. http://dx.doi.org/10.1016/j. ajog.2008.04.051. PMid:18572147.

16. American College of Obstetricians and Gynecologists Women's Health Care Physicians. ACOG Practice Bulletin No. 138: Inherited thrombophilias in pregnancy. Obstet Gynecol. 2013;122(3):70617. http://dx.doi.org/10.1097/01.AOG.0000433981.36184.4e. PMid:23963422.

17. Paschôa AF, Guillaumon AT. Impact of screening on thrombophilia for patients with venous thrombosis. Int Angiol. 2006;25(1):52-9. PMid:16520725.

18. Anderson FA Jr, Spencer FA. Risk factors for venous thromboembolism. Circulation. 2003;107(23, Suppl 1):19-16. PMid:12814980.

19. Care A. Routine care for the healthy pregnant woman. London: National Institute for Health and Clinical Excellence; 2008.

20. Sultan AA, Tata LJ, West J, et al. Risk factors for first venous thromboembolism around pregnancy: a population-based cohort study from the United Kingdom. Blood. 2013;121(19):3953-61. http://dx.doi.org/10.1182/blood-2012-11-469551. PMid:23550034.

21. Home Office. Safety and justice: the government's proposals on domestic violence. London: RCOG; 2003 [citado 2019 nov 27]. http://webarchive.nationalarchives.gov.uk/20131205100653/ http://www.archive2.official-documents.co.uk/document/ cm58/5847/5847.pdf

22. Liu S, Rouleau J, Joseph KS, et al. Epidemiology of pregnancyassociated venous thromboembolism: a population-based study in Canada. J Obstet Gynaecol Can. 2009;31(7):611-20. http://dx.doi. org/10.1016/S1701-2163(16)34240-2. PMid:19761634.

23. Montenegro CAB, Rezende J Fo. Rezende: obstetrícia fundamental. Rio de Janeiro: Guanabara Koogan; 2017. p. 514-520.

24. Bates SM, Middeldorp S, Rodger M, James AH, Greer I. Guidance for the treatment and prevention of obstetric-associated venous thromboembolism. J Thromb Thrombolysis. 2016;41(1):92-128. http://dx.doi.org/10.1007/s11239-015-1309-0. PMid:26780741.

25. Bates SM, Greer IA, Middeldorp S, Veenstra DL, Prabulos AM, Vandvik PO. VTE, thrombophilia, antithrombotic therapy, and pregnancy: antithrombotic therapy and prevention of thrombosis, 9th ed: American College of Chest Physicians Evidence-Based Clinical Practice Guidelines. Chest. 2012;141(2, Suppl):e691S-736S. http://dx.doi.org/10.1378/chest.11-2300. PMid:22315276.

26. Chan WS, Rey E, Kent NE, et al. Venous thromboembolism and antithrombotic therapy in pregnancy. J Obstet Gynaecol Can. 2014;36(6):527-53. http://dx.doi.org/10.1016/S1701-2163(15)305697. PMid:24927193.

27. James A. Practice bulletin no. 123: thromboembolism in pregnancy. Obstet Gynecol. 2011;118(3):718-29. http://dx.doi.org/10.1097/ AOG.0b013e3182310c4c. PMid:21860313.

28. Royal College of Obstetricians and Gynaecologists. Thrombosis and embolism during pregnancy and the puerperium: acute management (Green-top Guideline No. 37b). London: RCOG; 2015 [citado 2019 nov 27]. https://www.rcog.org.uk/en/guidelines-research-services/ guidelines/gtg37b

29. Royal College of Obstetricians and Gynaecologists. Thrombosis and embolism during pregnancy and the puerperium: acute management (Green-top Guideline No. 37b). London: RCOG; 2016 [citado 2019 
nov 27]. https://www.rcog.org.uk/en/guidelines-research-services/ guidelines/gtg37b

30. American College of Obstetricians and Gynecologists. ACOC Practice Bulletin No. 110: noncontraceptive uses of hormonal contraceptives. Obstet Gynecol. 2010;115(1):206-18. http://dx.doi. org/10.1097/AOG.0b013e3181cb50b5. PMid:20027071.

31. Reid R, Leyland N, Wolfman W, et al. Oral contraceptives and the risk of venous thromboembolism: an update. J Obstet Gynaecol Can. 2010;32(12):1192-204. http://dx.doi.org/10.1016/S17012163(16)34746-6. PMid:21176332.

32. Vieira R, Dal Fabbro AL, Rodrigues AL Jr. Características do uso de métodos anticoncepcionais, o Estado de São Paulo. Rev Saude Publica. 2002;36(3):263-70. http://dx.doi.org/10.1590/S003489102002000300002 . PMid: 12131963.

33. Stegeman BH, de Bastos M, Rosendaal FR, et al. Different combined oral contraceptives and the risk of venous thrombosis: systematic review and network meta-analysis. BMJ. 2013;347(sep12 1):f5298. http://dx.doi.org/10.1136/bmj.f5298. PMid:24030561.

34. Dinger JC, Heinemann LA, Kuhl-Habich D. The safety of a drospirenone containing oral contraceptive: final results from the European Active Surveillance Study on oral contraceptives based on 142,475 womenyears of observation. Contraception. 2007;75(5):344-54. http:// dx.doi.org/10.1016/j.contraception.2006.12.019. PMid:17434015.

35. Pomp ER, Lenselink AM, Rosendaal FR, Doggen CJ. Pregnancy, the postpartum period and prothrombotic defects: risk of venous thrombosis in the MEGA study. J Thromb Haemost. 2008;6(4):632-7. http://dx.doi.org/10.1111/j.1538-7836.2008.02921.x. PMid:18248600.

36. Gallo MF, Nanda K, Grimes DA, Schulz KF. Twenty micrograms vs. $>20$ mcg estrogens oral contraceptives for contraception: systematic review of randomized controlled trials. Contraception. 2005;71(3):162-9. http://dx.doi.org/10.1016/j.contraception.2004.09.005. PMid:15722064.

37. Conard J. Biological coagulation findings in third-generation oral contraceptives. Hum Reprod Update. 1999;5(6):672-80. http:// dx.doi.org/10.1093/humupd/5.6.672. PMid:10652977.

38. Blanco-Molina A. Oral contraception in women with mild thrombophilia: what have we learned recently? Thromb Res. 2012;130(Suppl 1):S16-8. http://dx.doi.org/10.1016/j. thromres.2012.08.263. PMid:23026651.

39. Vandenbroucke JP, Koster T, Rosendaal FR, Briët E, Reitsma $\mathrm{PH}$, Bertina RM. Increased risk of venous thrombosis in oralcontraceptive users who are carriers of factor $\mathrm{V}$ Leiden mutation. Lancet. 1994;344(8935):1453-7. http://dx.doi.org/10.1016/S01406736(94)90286-0. PMid:7968118.

40. Eichinger S, Evers JLH, Glasier A, et al. Venous thromboembolism in women: a specific reproductive health risk. Hum Reprod Update. 2013;19(5):471-82. http://dx.doi.org/10.1093/humupd/dmt028. PMid:23825156.

41. WHO Expert Group. Medical eligibility criteria for contraceptive use: reproductive health and research. 4th ed. Geneva: WHO.

42. Bezemer ID, van der Meer FJ, Eikenboom JC, Rosendaal FR, Doggen C). The value of family history as a risk indicator for venous thrombosis. Arch Intern Med. 2009;169(6):610-5. http://dx.doi. org/10.1001/archinternmed.2008.589. PMid:19307525.

43. Sonnevi K, Bergendal A, Adami J, Larfars G, Kieler H. Self-reported family history in estimating the risk of hormone, surgery and cast related VTE in women. Thromb Res. 2013;132(2):164-9. http:// dx.doi.org/10.1016/j.thromres.2013.06.003. PMid:23800637.

44. World Health Organization. Effect of different progestagens in low oestrogen oral contraceptives on venous thromboembolic disease. WHO Collaborative Study of Cardiovascular Disease and
Steroid Hormone Contraception. Lancet. 1995;346(8990):1582-8. http://dx.doi.org/10.1016/S0140-6736(95)91927-9. PMid:7500749.

45. Lidegaard O, Nielsen LH, Skovlund CW, Lokkegaard E. Venous thrombosis in users of non-oral hormonal contraception: follow-up study, Denmark 2001-10. BMJ. 2012;344(3):e2990. http://dx.doi. org/10.1136/bmj.e2990. PMid:22577198.

46. Suissa S, Blais L, Spitzer WO, Cusson J, Lewis M, Heinemann L. First-time use of newer oral contraceptives and the risk of venous thromboembolism. Contraception. 1997;56(3):141-6. http://dx.doi. org/10.1016/S0010-7824(97)00119-4. PMid:9347203.

47. McCann MF, Potter LS. Progestin-only oral contraception: a comprehensive review. Contraception. 1994;50(6, Suppl 1):S1-195. http://dx.doi.org/10.1016/0010-7824(94)90113-9. PMid:10226677.

48. Tchaikovski S, Rosendaal F, Rosing J, Helmerhorst F, Van Vliet H. The effect of the levonorgestrel-releasing intrauterine system on the resistance to activated protein C (APC). Thromb Haemost. 2009;101(4):691-5. http://dx.doi.org/10.1160/TH08-09-0621. PMid:19350113.

49. Van Voorhis BJ. Clinical practice. In vitro fertilization. N Engl J Med. 2007;356(4):379-86. http://dx.doi.org/10.1056/NEJMcp065743. PMid:17251534.

50. Steptoe PC, Edwards RG. Birth after the reimplantation of a human embryo. Lancet. 1978;2(8085):366. http://dx.doi.org/10.1016/ S0140-6736(78)92957-4. PMid:79723.

51. The Nobel Assembly at Karolinska Institutet. Human in vitro fertilization. Stockholm; 2010 [citado 2019 nov 27]. http://static. nobelprize.org/nobel_prizes/medicine/laureates/2010/adv.pdf

52. Malizia BA, Hacker MR, Penzias AS. Cumulative live-birth rates after in vitro fertilization. N Engl J Med. 2009;360(3):236-43. http:// dx.doi.org/10.1056/NEJMoa0803072. PMid:19144939.

53. Mára M, Koryntova D, Rezabek K, et al. Thromboembolic complications in patients undergoing in vitro fertilization: retrospective clinical study. Ceska Gynekol. 2004;69(4):312-6. PMid:15369253.

54. Chan WS, Ginsberg JS. A review of upper extremity deep vein thrombosis in pregnancy: unmasking the 'ART' behind the clot. J Thromb Haemost. 2006;4(8):1673-7. http://dx.doi.org/10.1111/ j.1538-7836.2006.02026.x. PMid:16879207.

55. Delvigne A, Demoulin A, Smitz J, et al. The ovarian hyperstimulation syndrome in in-vitro fertilization: a Belgian multicentric study. I. Clinical and biological features. Hum Reprod. 1993;8(9):135360. http://dx.doi.org/10.1093/oxfordjournals.humrep.a138260. PMid:8253917.

56. Abramov Y, Elchalal U, Schenker JG. Obstetric outcome of in vitro fertilized pregnancies complicated by severe ovarian hyperstimulation syndrome: a multicenter study. Fertil Steril. 1998;70(6):1070-6. http://dx.doi.org/10.1016/S0015-0282(98)00350-1. PMid:9848297.

57. Serour Gl, Aboulghar M, Mansour R, Sattar MA, Amin Y, Aboulghar H. Complications of medically assisted conception in 3,500 cycles. Fertil Steril. 1998;70(4):638-42. http://dx.doi.org/10.1016/S00150282(98)00250-7. PMid:9797090.

58. Budev MM, Arroliga AC, Falcone T. Ovarian hyperstimulation syndrome. Crit Care Med. 2005;33(10, Suppl):S301-6. http://dx.doi. org/10.1097/01.CCM.0000182795.31757.CE. PMid:16215351.

59. Rova K, Passmark H, Lindqvist PG. Venous thromboembolism in relation to in vitro fertilization: an approach to determining the incidence and increase in risk in successful cycles. Fertil Steril. 2012;97(1):95-100. http://dx.doi.org/10.1016/j.fertnstert.2011.10.038. PMid:22118992.

60. Chan WS. The 'ART' of thrombosis: a review of arterial and venous thrombosis in assisted reproductive technology. Curr Opin 
Obstet Gynecol. 2009;21(3):207-18. http://dx.doi.org/10.1097/ GCO.0b013e328329c2b8. PMid:19276806.

61. Chan WS, Dixon ME. The "ART" of thromboembolism: a review of assisted reproductive technology and thromboembolic complications. Thromb Res. 2008;121(6):713-26. http://dx.doi. org/10.1016/j.thromres.2007.05.023. PMid:17659766.

62. Klemetti R, Sevon T, Gissler M, Hemminki E. Complications of IVF and ovulation induction. Hum Reprod. 2005;20(12):3293-300. http://dx.doi.org/10.1093/humrep/dei253. PMid:16126753.

63. Whelan JG 3rd, Vlahos NF. The ovarian hyperstimulation syndrome. Fertil Steril. 2000;73(5):883-96. http://dx.doi.org/10.1016/S00150282(00)00491-X. PMid:10785212.

64. Ou YC, Kao YL, Lai SL, et al. Thromboembolism after ovarian stimulation: successful management of a woman with superior sagittal sinus thrombosis after IVF and embryo transfer: case report. Hum Reprod. 2003;18(11):2375-81. http://dx.doi.org/10.1093/ humrep/deg470. PMid:14585890.

65. Bauersachs RM, Manolopoulos K, Hoppe I, Arin MJ, Schleussner E. More on: the 'ART' behind the clot: solving the mystery. J Thromb Haemost. 2007;5(2):438-9. http://dx.doi.org/10.1111/j.15387836.2007.02339.x. PMid:17269941.

66. Richardson MA, Berg DT, Calnek DS, Ciaccia AV, Joyce DE, Grinnell BW. 17beta-estradiol, but not raloxifene, decreases thrombomodulin in the antithrombotic protein $C$ pathway. Endocrinology. 2000;141(10):3908-11. http://dx.doi.org/10.1210/ endo.141.10.7798. PMid:11014248.

67. Salomon O, Schiby G, Heiman Z, et al. Combined jugular and subclavian vein thrombosis following assisted reproductive technology-new observation. Fertil Steril. 2009;92(2):620-5. http:// dx.doi.org/10.1016/j.fertnstert.2008.07.1708. PMid:18710711.

68. Stewart JA, Hamilton PJ, Murdoch AP. Thromboembolic disease associated with ovarian stimulation and assisted conception techniques. Hum Reprod. 1997;12(10):2167-73. http://dx.doi. org/10.1093/humrep/12.10.2167. PMid:9402276

69. Scarabin PY. Hormone therapy and venous thromboembolism among postmenopausal women. Front Horm Res. 2014;43:21-32. http://dx.doi.org/10.1159/000360554. PMid:24943295.

70. Oger E. Incidence of venous thromboembolism: a community-based study in Western France. EPI-GETBP Study Group. Groupe d'Etude de la Thrombose de Bretagne Occidentale. Thromb Haemost. 2000;83(5):657-60. http://dx.doi.org/10.1055/s-0037-1613887. PMid:10823257.

71. Olié V, Canonico M, Scarabin PY. Risk of venous thrombosis with oral versus transdermal estrogen therapy among postmenopausal women. Curr Opin Hematol. 2010;17(5):457-63. http://dx.doi. org/10.1097/MOH.0b013e32833c07bc. PMid:20601871.

72. Canonico M. Hormone therapy and risk of venous thromboembolism among postmenopausal women. Maturitas. 2015;82(3):304-7. http://dx.doi.org/10.1016/j.maturitas.2015.06.040. PMid:26276103.

73. Anderson FA Jr, Wheeler HB, Goldberg RJ, et al. A population-based perspective of the hospital incidence and case-fatality rates of deep vein thrombosis and pulmonary embolism: the Worcester DVT Study. Arch Intern Med. 1991;151(5):933-8. http://dx.doi. org/10.1001/archinte.1991.00400050081016. PMid:2025141.

74. Rossouw JE, Anderson GL, Prentice RL, et al. Risks and benefits of estrogen plus progestin in healthy postmenopausal women: principal results From the Women's Health Initiative randomized controlled trial.JAMA. 2002;288(3):321-33. http://dx.doi.org/10.1001/ jama.288.3.321. PMid:12117397.

75. Granata R. IJeCliE, Front Horm Res. Basel K. 2014;43:21-32. http:// dx.doi.org/10.1159/000360554.
76. Daly E, Vessey MP, Hawkins MM, Carson JL, Gough P, Marsh S. Risk of venous thromboembolism in users of hormone replacement therapy. Lancet. 1996;348(9033):977-80. http://dx.doi.org/10.1016/ S0140-6736(96)07113-9. PMid:8855852.

77. Pérez Gutthann S, Rodriguez L. A G., Castellsague J, Oliart AD. Hormone replacement therapy and risk of venous thromboembolism: population based case control study. BMJ. 1997;314(7083):796-800. http://dx.doi.org/10.1136/bmj.314.7083.796. PMid:9081000.

78. Høibraatenn E, Abdelnoor M, Sandset PM. Hormone replacement therapy with estradiol and risk of venous thromboembolism: a population-based case-control study. Thromb Haemost. 1999;82(4):1218-21. PMid:10544901.

79. Douketis JD, Julian JA, Kearon C, et al. Does the type of hormone replacement therapy influence the risk of deep vein thrombosis? A prospective case-control study. J Thromb Haemost. 2005;3(5):943-8. http://dx.doi.org/10.1111/j.1538-7836.2005.01268.x. PMid:15869589.

80. Scarabin PY, Oger E, Plu-Bureau G. Differential association of oral and transdermal oestrogen-replacement therapy with venous thromboembolism risk. Lancet. 2003;362(9382):428-32. http:// dx.doi.org/10.1016/S0140-6736(03)14066-4. PMid:12927428.

81. Canonico $M$, Oger E, Plu-Bureau G, et al. Hormone therapy and venous thromboembolism among postmenopausal women: impact of the route of estrogen administration and progestogens: the ESTHER study. Circulation. 2007;115(7):840-5. http://dx.doi. org/10.1161/CIRCULATIONAHA.106.642280. PMid:17309934.

82. Renoux C, Dell'Aniello S, Suissa S. Hormone replacement therapy and the risk of venous thromboembolism: a population-based study. J Thromb Haemost. 2010;8(5):979-86. PMid:20230416.

83. Canonico M, Fournier A, Carcaillon L, et al. Postmenopausal hormone therapy and risk of idiopathic venous thromboembolism: results from the $\mathrm{E} 3 \mathrm{~N}$ cohort study. Arterioscler Thromb Vasc Biol. 2010;30(2):340-5. http://dx.doi.org/10.1161/ATVBAHA.109.196022. PMid:19834106.

84. Sweetland S, Beral V, Balkwill A, et al. Venous thromboembolism risk in relation to use of different types of postmenopausal hormone therapy in a large prospective study. J Thromb Haemost. 2012;10(11):2277-86. http://dx.doi.org/10.1111/j.15387836.2012.04919.x. PMid:22963114.

85. Roach RE, Lijfering WM, Helmerhorst FM, Cannegieter SC, Rosendaal FR, van Hylckama Vlieg A. The risk of venous thrombosis in women over 50 years old using oral contraception or postmenopausal hormone therapy. J Thromb Haemost. 2013;11(1):124-31. http:// dx.doi.org/10.1111/jth.12060. PMid:23136837.

86. Canonico M, Plu-Bureau G, Scarabin PY. Progestagens and venous thromboembolism among postmenopausal women using hormone therapy. Maturitas. 2011;70(4):354-60. http://dx.doi.org/10.1016/j. maturitas.2011.10.002. PMid:22024394.

87. Canonico M, Plu-Bureau G, Lowe GD, Scarabin PY. Hormone replacement therapy and risk of venous thromboembolism in postmenopausal women: systematic review and meta-analysis. BMJ. 2008;336(7655):1227-31. http://dx.doi.org/10.1136/ bmj.39555.441944.BE. PMid:18495631.

88. Hulley S, Grady D, Bush T, et al. Randomized trial of estrogen plus progestin for secondary prevention of coronary heart disease in postmenopausal women. Heart and Estrogen/progestin Replacement Study (HERS) Research Group. JAMA. 1998;280(7):605-13. http:// dx.doi.org/10.1001/jama.280.7.605. PMid:9718051.

89. Høibraaten E, Qvigstad E, Arnesen H, Larsen S, Wickstrom E, Sandset PM. Increased risk of recurrent venous thromboembolism during hormone replacement therapy: results of the randomized, doubleblind, placebo-controlled estrogen in venous thromboembolism trial (EVTET). Thromb Haemost. 2000;84(6):961-7. PMid:11154141. 
90. Cushman M, Kuller LH, Prentice R, et al. Estrogen plus progestin and risk of venous thrombosis. JAMA. 2004;292(13):1573-80. http://dx.doi.org/10.1001/jama.292.13.1573. PMid:15467059.

91. Curb JD, Prentice RL, Bray PF, et al. Venous thrombosis and conjugated equine estrogen in women without a uterus. Arch Intern Med. 2006;166(7):772-80. http://dx.doi.org/10.1001/ archinte.166.7.772. PMid:16606815.

92. Vickers MR, MacLennan AH, Lawton B, et al. Main morbidities recorded in the women's international study of long duration oestrogen after menopause (WISDOM): a randomised controlled trial of hormone replacement therapy in postmenopausa women. BMJ. 2007;335(7613):239. http://dx.doi.org/10.1136/ bmj.39266.425069.AD. PMid:17626056.

93. Scarabin PY, Hemker HC, Clement C, Soisson V, Alhenc-Gelas M. Increased thrombin generation among postmenopausal women using hormone therapy: importance of the route of estrogen administration and progestagens. Menopause. 2011;18(8):873-9. http://dx.doi.org/10.1097/gme.0b013e31820eee88. PMid:21487317.

94. Scarabin PY, Alhenc-Gelas M, Plu-Bureau G, Taisne P, Agher R, Aiach $M$. Effects of oral and transdermal estrogen/progesterone regimens on blood coagulation and fibrinolysis in postmenopausal women. A randomized controlled trial. Arterioscler Thromb Vasc Biol. 1997;17(11):3071-8. http://dx.doi.org/10.1161/01.ATV.17.11.3071. PMid:9409295.

95. Oger E, Alhenc-Gelas M, Lacut K, et al. Differential effects of oral and Transdermal estrogen/progesterone regimens on sensitivity to activated protein C among postmenopausal women: a randomized trial. Arterioscler Thromb Vasc Biol. 2003;23(9):1671-6. http:// dx.doi.org/10.1161/01.ATV.0000087141.05044.1F.PMid:12869355.

96. Canonico M, Alhenc-Gelas M, Plu-Bureau G, Olie V, Scarabin PY. Activated protein $C$ resistance among postmenopausal women using transdermal estrogens: importance of progestogen. Menopause. 2010;17(6):1122-7. http://dx.doi.org/10.1097/gme.0b013e3181e102eb. PMid:20613675.

97. Marjoribanks J, Farquhar C, Roberts H, Lethaby A. Long term hormone therapy for perimenopausal and postmenopausal women. Cochrane Database Syst Rev. 2012;(7):CD004143. http:// dx.doi.org/10.1002/14651858.CD004143.pub4. PMid:22786488.

98. Olié V, Plu-Bureau G, Conard J, Horellou MH, Canonico M, Scarabin PY. Hormone therapy and recurrence of venous thromboembolism among postmenopausal women. Menopause. 2011;18(5):488-93. http://dx.doi.org/10.1097/gme.0b013e3181f9f7c3. PMid:21178641.

99. North American Menopause Society. The 2012 hormone therapy position statement of: The North American Menopause Society. Menopause. 2012;19(3):257-71. http://dx.doi.org/10.1097/ gme.0b013e31824b970a. PMid:22367731.

100.Tremollieres F, Brincat M, Erel CT, et al. EMAS position statement: managing menopausal women with a personal or family history of VTE. Maturitas. 2011;69(2):195-8. http://dx.doi.org/10.1016/j. maturitas.2011.03.011. PMid:21489728.

Correspondence Marcos Arêas Marques Universidade do Estado do Rio de Janeiro - UERJ, Hospital Universitário Pedro Ernesto, Unidade Docente Assistencial de Angiologia Rua Assunção, 217/704 - Botafogo CEP 22251-030 - Rio de Janeiro (RJ), Brazil Tel.: +55 (21) 99859-0160

E-mail: mareasmarques@gmail.com

Author information ALMLO - Director of Ginecologia, Centro de Referência da Saúde da Mulher de São Paulo.

AFP - Co-responsible, Serviço de Cirurgia Vascular Integrada, Beneficência Portuguesa de São Paulo; PhD in Cirurgia, UNICAMP. MAM - Angiologist, Unidade Docente Assistencial de Angiologia, Hospital Universitário Pedro Ernesto (HUPE), Universidade do Estado do Rio de Janeiro (UERJ).

Author contributions Conception and design: MAM, ALMLO, AFP Analysis and interpretation: MAM, ALMLO, AFP Data collection: MAM, ALMLO, AFP Writing the article: MAM, ALMLO, AFP Critical revision of the article: MAM, ALMLO, AFP Final approval of the article*: MAM, ALMLO, AFP Statistical analysis: N/A. Overall responsibility: MAM, ALMLO, AFP

*All authors have read and approved of the final version of the article submitted to I Vasc Bras. 